\title{
PEMBELAJARAN DARING DI PERGURUAN TINGGI: PERSEPSI DAN FAKTOR PENENTU
}

\author{
Zuni Mitasari ${ }^{1}$ \\ Yuswa Istikomayanti ${ }^{2}$ \\ Rudy Setiawan ${ }^{3}$ \\ ${ }^{1,2)}$ Pendidikan Biologi Universitas Tribhuwana Tunggadewi \\ ${ }^{3}$ Pendidikan Matematika Universitas Tribhuwana Tunggadewi \\ E-mail: ${ }^{1}$ zmitasari@gmail.com, ${ }^{2} y u s w a 2710 @ g m a i l . c o m, ~{ }^{3}$ rudiehabibi@gmail.com
}

\begin{abstract}
This study aims to reveal the perceptions of students and lecturers on courageous learning due to the Covid-19 pandemic, as well as to reveal the determining factors in learning. This type of this research is qualitative descriptive. Sampling was carried out using purposive sampling on Biology Education students and lecturers at the University of Tribhuwana Tunggadewi. The research instrument used was a questionnaire to collect information about the perceptions of students and lecturers related to courageous learning. The research data focuses on three aspects, namely the teaching and learning process, the capabilities of the lecturers, and the supporting facilities and infrastructure for lectures. Based on the research results, it can be seen that students have various perceptions related to bold learning. In addition, the determinants of bold learning investment are human resources, technology, and facilities, and infrastructure.
\end{abstract}

Kata kunci: covid-19, faktor penentu, pembelajaran daring, perguruan tinggi, persepsi

\section{PENDAHULUAN}

Corona Virus Diseases (Covid19) merupakan wabah penyakit yang menyebabkan pandemi global. Kasus penyakit ini ditemukan pertama kali di Indonesia pada awal bulan Maret 2020. Pandemi Covid-19 memberikan dampak yang signifikan pada berbagai aspek kehidupan, salah satunya adalah dalam bidang pendidikan. World Health Organization (WHO) menghimbau agar acara-acara yang menyebabkan kerumunan dihentikan guna mendukung upaya pencegahan Covid-19. Pembelajaran tatap muka haruslah diubah menjadi pembelajaran daring.

Pembelajaran daring diambil sebagai langkah untuk merespon adanya pandemi Covid-19. Siswa mulai dari tingkat pendidikan dasar dan menengah sampai mahasiswa di perguruan tinggi melakukan proses belajar mengajar secara daring.
Perkuliahan

hendaknya

diselenggarakan dengan aturan yang dapat mencegah terjadinya interaksi fisik antar mahasiswa atau interaksi antara dosen dengan mahasiswa (Firman dan Rahayu, 2020).

Hal tersebut didukung dengan adanya kebijakan Menteri Pendidikan dan Kebudayaan (Mendikbud) melalui surat edaran Nomor 4 Tahun 2020 tentang pelaksanaan pendidikan dalam masa darurat Covid-19. Selain itu juga didukung oleh kebijakan Mendikbud, yaitu surat edaran Nomor 3 Tahun 2020 tentang pencegahan Covid-19 pada tingkat satuan pendidikan. Mengacu pada surat edaran tersebut, Universitas Tribhuwana Tunggadewi Malang juga menerapkan pembelajaran daring bagi semua mahasiswa mulai semester genap tahun akademik 2019/2020.

Penggunaan teknologi digital memungkinkan dosen dan mahasiswa mengadakan proses pembelajaran 
meskipun keduanya berada di tempat berbeda (Milman, 2015). Pembelajaran daring dapat dilakukan dengan menggunakan google classroom, zoom meeting, dan video conference serta didukung dengan menggunakan whatssapp group untuk memudahkan pemantauan dan pendampingan (Dewi, 2020). Google classroom dan zoom meeting merupakan platform online yang banyak digunakan di perguruan tinggi untuk melaksanakan kegiatan belajar mengajar secara daring (Pratiwi, 2020).

Pembelajaran daring adalah sebuah inovasi dalam dunia pendidikan yang melibatkan peran teknologi informasi dalam kegiatan pembelajaran (Fitriyani dkk, 2020). Dampak positif dari pembelajaran daring yaitu tersedianya akses belajar untuk semua sehingga permasalahan yang mengharuskan belajar di dalam kelas dapat diatasi (Riaz, 2018). Meskipun ditemukan banyak dampak positif pada pembelajaran daring tetapi yang perlu diingat bahwa teknologi tidak serta merta dapat menggantikan peran dosen dalam mengajar di kelas. Hal tersebut didukung oleh penelitian Pilkington (2018) yang menyatakan bahwa tidak semua kegatan belajar dapat dipindahkan ke dalam pembelajaran online.

Dosen selaku pendidik dan fasilitator pembelajaran di perguruan tinggi haruslah memiliki kemampuan dalam menggunakan teknologi digital. Hal tersebut bertujuan untuk memfasilitasi dan menciptakan suasana pembelajaran yang nyaman dan kondusif. Implementasi pembelajaran daring hendaknya tidak mengurangi esensi dalam pembelajaran seperti sebelum ada pandemi Covid-19. Pembelajaran haruslah tetap berorientasi pada Student Centered Learning (SCL).

Mahasiswa sebagai pusat dalam kegiatan pembelajaran masih menjadi tantangan di masa pandemi Covid-19 seperti ini. Tantangan pembelajaran muncul ketika ada pertanyaan, bagaimana tingkat partisipasi dosen dan mahasiwa dalam pembelajaran daring akibat pandemi Covid-19?, Agar pembelajaran daring dapat berjalan secara efektif, maka perlu untuk melakukan evaluasi secara berkelanjutan (Saragih dkk, 2020).

Berdasarkan latar belakang tersebut, maka tujuan penelitian ini adalah untuk mengeksplorasi persepsi dosen dan mahasiswa dalam pembelajaran daring akibat pandemi Covid-19 dan menganalisis faktor penentu dalam keberhasilan pembelajaran daring.

\section{METODE}

Penelitian ini menggunakan pendekatan deskriptif kualitatif. Pengambilan sampel dilakukan dengan menggunakan purposive sampling pada 44 mahasiswa Pendidikan Biologi Fakultas Ilmu Pendidikan dan 111 dosen Universitas Tribhuwana Tunggadewi. Penelitian dilakukan pada semester Ganjil 2020/2021. Instrumen penelitian yang digunakan yaitu kuesioner untuk mengumpulkan informasi tentang persepsi mahasiswa dan dosen terkait pembelajaran daring. Pengambilan data dilakukan secara online melalui google form. Data penelitian ini berupa data kuantitatif yang menitikberatkan pada tiga aspek, yaitu kegiatan proses belajar mengajar, kapabilitas dosen serta sarana dan prasarana penunjang perkuliahan.

Tahapan analisis data pada penelitian ini menggunakan model analisis Miles \& Huberman, yang terdiri atas (1) reduksi data penelitian, (2) display data penelitian, dan (3) penarikan dan verifikasi kesimpulan. Pada tahap reduksi data, semua informasi dikumpulkan kemudian dikelompokkan berdasarkan 
peruntukannya. Pada tahap display data, dilakukan pemaparan data yang diperlukan dalam kegiatan penelitian, dan pada tahap penarikan dan verifikasi kesimpulan, kegiatan yang dilakukan yaitu interpretasi data penelitian sehingga bisa ditarik kesimpulan berdasarkan fenomena yang telah didapatkan (Miles dan Huberman, 1994).

Berikut adalah gambar model analisis data tersebut:

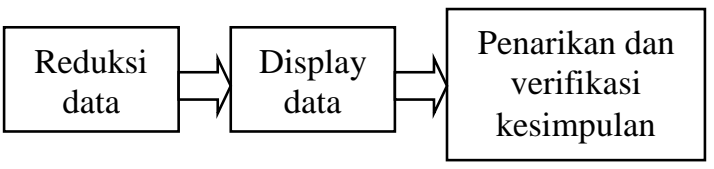

Gambar 1: Tahapan Analisis Data Penelitian Model Miles \& Huberman

\section{HASIL}

Apakah Anda mengalami kesulitan dengan pelaksanaan pembelajaran daring? 44 tanggapan
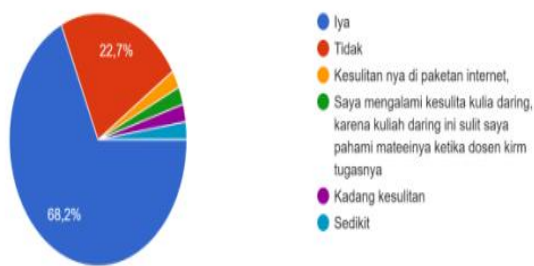

Gambar 2. Diagram Kesulitan Mahasiswa pada Pelaksanaan Pembelajaran Daring

Berdasarkan data penelitian yang tersaji pada Gambar 2 tersebut dapat diketahui bahwa pada semester awal dilaksanakannya pembelajaran daring $66.2 \%$ mahasiswa mengalami kesulitan terhadap pembelajaran daring. Sebanyak $22.7 \%$ mahasiswa Pendidikan Biologi tidak mengalami kesulitan.

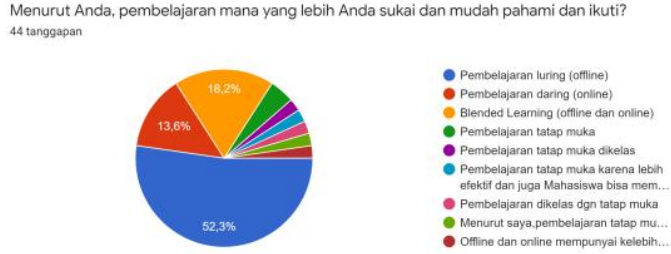

Gambar 3. Kecenderungan Persepsi Mahasiswa terhadap Pembelajaran Daring dan Luring

Berdasarkan data pada Gambar 3. Dapat diketahui bahwa $52.3 \%$ mahasiswa memiliki kecenderungan untuk lebih memilih pembelajaan luring atau offline jika dibandingkan dengan $13.6 \%$ mahasiswa yang lebih menyukai pembelajaran daring atau online sedangkan $18.2 \%$ mahasiswa menyukai pembelajaran blended learning (offline dan online).

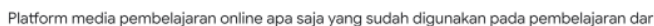
semester genap TA. 20jaran on semester genap TA. 2019/2020

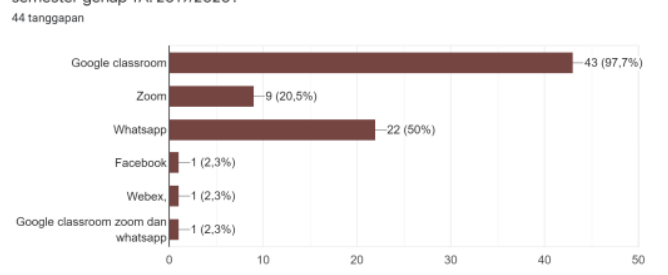

Gambar 4. Persepsi Mahasiswa terhadap Pemilihan Platform Media Pembelajaran Online

Berdasarkan data pada Gambar 4. Tersebut dapat diketahui bahwa berikut adalah urutan platform media pembelajaran online mulai dari yang paling banyak digunakan dalam pembelajaran daring, google classroom (97.7\%), whatsapp (50\%), zoom meeting (20.5\%), dan masing-masing $2.3 \%$ untuk penggunan media facebook dan webex.

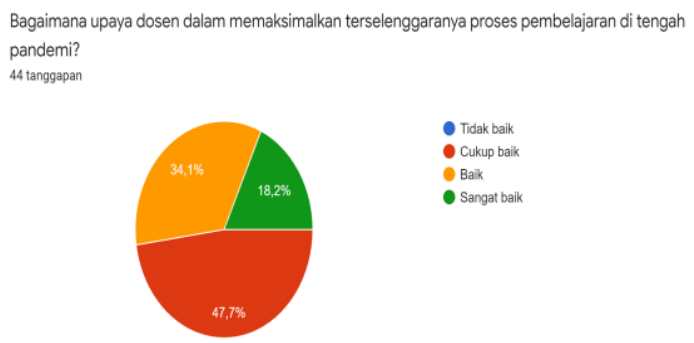

Gambar 5. Upaya Dosen dalam Penyelenggaraan Perkuliahan Daring 
Berdasarkan data pada Gambar 5. tersebut dapat diketahui bahwa menurut mahasiswa sebanyak $47.7 \%$ dosen sudah cukup maksimal dalam mengajar daring, $34.1 \%$ baik, dan $18.2 \%$ mahasiswa mengatakan dosen sangat baik dalam mengajar.

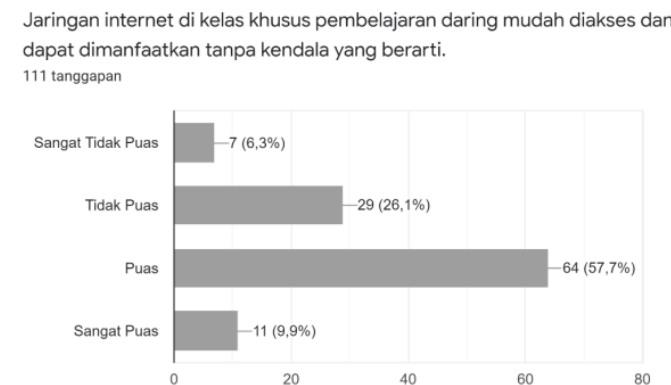

Gambar 6. Persepsi Dosen terhadap Sarana dan Prasarana Perkuliahan

Berdasarkan Gambar 6 tersebut bahwa sebanyak $57.7 \%$ dosen merasa puas dengan fasilitas internet yang disediakan, $26.1 \%$ merasa tidak puas, 9.9\% sangat puas, dan sebanyak $6.3 \%$ dosen merasa sangat tidak puas.

\section{PEMBAHASAN}

\section{Persepsi Mahasiswa dan Dosen terhadap Pembelajaran Daring}

Berdasarkan hasil analisis data diketahui bahwa pada awal semester diimplementasikannya pembelajaran daring sebanyak $66.2 \%$ mahasiswa mengalami kesulitan. Pada tiga bulan pertama dilaksanakannya perkuliahan daring, mahasiswa cenderung memiliki persepsi negatif, menganggapnya membosankan dan membuat jenuh (Aswasulasikin, 2020). Mahasiswa lebih memilih pembelajaran luring $(52.3 \%)$ jika dibandingkan pembelajaran daring, menurut mereka pembelajaran luring lebih efektif karena lebih banyak interaksi dan diskusi dengan dosen maupun antar mahasiswa. Hal tersebut menciptakan komunikasi yang efektif dan iklim pembelajaran yang kondusif.
Pada pembelajaran daring ketersediaan fasilitas belajar dan persepsi mahasiswa dapat meningkatkan sikap mandiri dan motivasi belajar mahasiswa (Sadikin dan Hamidah, 2020). Google classroom merupakan platform media online yang paling banyak digunakan dalam pembelajaran daring, yaitu sebesar $97.7 \%$. pendidik diharapkan dapat mengimplementasikan pembelajaran asinkron dan sinkron untuk meningkatkan prestasi belajar pada pembelajaran jarak jauh (Sulistio, 2021).

Dosen di perguruan tinggi
diharapkan untuk mampu
menyelenggarakan kegiatan pembelajaran asinkron dan sinkron. Pada pembelajaran sinkron, kegiatan pembelajaran dilakukan pada waktu yang sama meskipun dosen dan mahasiswa terpisah jarak dengan menggunakan chatting, audio conference, maupun video conference. Berbeda dengan pembelajaran sinkron, pada pembelajaran asinkron kegiatan pembelajaran dilakukan dalam waktu berbeda, seperti $e$-mail dan materi yang dishare dapat direspon oleh dosen mapun mahasiswa kapanpun (Ristekbrin, 2017).

\section{Faktor Penentu Kebehasilan Pembelajaran Daring}

\section{Sumber Daya Manusia}

Sumber Daya Manusia (SDM) merupakan salah satu aspek penentu dalam keberhasilan pembelajaran daring. SDM yang dimaksud di sini tidak hanya pendidik tetapi juga mahasiswa. Keuntungan pembelajaran daring adalah tumbuhnya keberanian dalam mengemukakan pertanyaan dan gagasan (Sadikin dan Hamidah, 2020) di sisi lain hambatan dalam pembelajaran daring juga dapat menurunkan belajar mahasiswa (Suryani, 2010). Pembelajan daring juga dapat dikatakan sebagai proses 
transformasi dari pendidikan konvensional ke bentuk digital. Hal baru tersebut, pada akhirnya menciptakan tantangan dan juga peluang (Harjanto dan Sumunar, 2018).

Perguruan tinggi dan dosen sebagai pendidik memiliki peran dan sumbangsih dalam mendukung keberhasilan dalam pelaksanaan pembelajaran daring (Rusdiana dan Nugroho, 2020). Pihak-pihak yang terlibat dalam pelaksanaan pembelajaran daring, dalam hal ini pendidik dan mahasiswa memiliki peran yang berbeda tetapi saling mendukung untuk keberlanjutan pembelajaran daring. Hambatan dalam pembelajaran daring juga ditemukan, salah satunya yaitu mempengaruhi kondisi psikologis mahasiswa. Oleh karena itu, mahasiswa perlu dibekali kemampuan dalam mengelola stress (Jamaludin dkk, 2020).

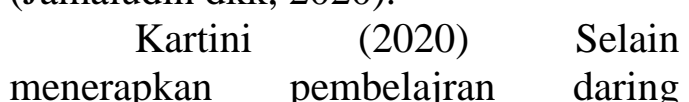
sebagai seorang pendidik harus dapat menggunkan metode yang tepat dalam pembelajaran di kelas, baik tepat dengan materi pembelajaran atau kondisi peserta didik. terdapat berbagai bahan ajar interaktif juga dapat meningkatkan diskusi dan keaktifan peserta didik serta sehingga wawasan peserta didik bertambah, materi yang sulit terselesaikan melalui diskusi interaktif.

\section{Teknologi}

Perkembangan dalam ilmu pengetahuan di bidang Teknologi Informasi dan Komunikasi (TIK) berpengaruh besar terhadap berbagai aspek kehidupan, salah satunya dalam dunia pendidikan. Perkembangan TIK memberikan sumbangsih terhadap peningkatan penggunaan internet di Indonesia (Rahadian, 2017). Penggunaan TIK dalam pembelajaran daring memiliki kelebihan yaitu tidak terikatnya ruang dan waktu. Meskipun demikian, pelaksanaan pembelajaran daring juga tidaklah mudah, (Pangondian dkk, 2019).

Berkaitan dengan cara belajar dan membelajarkan ilmu pengetahuan kepada manusiapun telah mengalami perubahan paradigma. Pada era sekarang pembelajaran menggunakan teknologi seperti e-learning. Tantangan e-learning terletak pada cara merancang pembelajarannya, tidak hanya berkaitan dengan teknologinya (Chaeruman, 2017). Satu hal yang tidak boleh dilupakan dalam pembelajaran daring menggunakan e-learning yaitu pembelajaran tersebut haruslah memberikan pengalaman belajar kepada mahasiswa, jangan sampai esensinya kurang jika dibandingkan dengan pembelajaran offline.

Teknologi dapat dimanfaatkan untuk membentuk pembelajar yang inovatif dan kondusif sehingga berperan dalam kesuksesan proses belajar mengajar (Anshori, 2018). Teknologi sebagai salah satu media pembelajaran dapat dioptimalkan perannya dalam pembelajaran daring. Media pembelajaran memudahkan dalam komunikasi di kelas. Komponen dalam kegiatan pembelajaran yang bisa mendukung komunikasi atau penyampaian informasi dengan baik yaitu dengan media pembelajaran (Masykhur dan Risnani, 2020).

\section{Sarana dan Prasarana}

Beberapa mahasiswa Pendidikan Biologi juga merasa pembelajaran daring kurang efektif. Hal tersebut dikarenakan jaringan internet di daerah asal mereka kurang bagus. Kebanyakan mahasiswa kami berasal dari Nusa Tenggara Timur dan Kalimantan Barat.

Pembelajaran daring tidak efektif karena (1) mahasiswa kesulitan memahami konsep, (2) kurangnya keterampilan mahasiswa dalam menggunakan aplikasi pembelajaran 
secara online, dan (3) akses internet tidak merata (Hadi, 2020). Selain itu, permasalahan yang terjadi dalam pembelajaran daring adalah pengawasan terhadap mahasiswa lemah, sinyal di daerah pelosok kurang bagus, serta biaya kuota internet cukup mahal (Sadikin dan Hamidah, 2020).

Pembelajaran yang efektif dan efisian akan terlaksana jika pesan dan informasi pembelajaran dapat tersampaikan dengan baik, (Anshori, 2018). Berdasarkan hasil analisis data dapat diketahui bahwa fasilitas atau sarana dan prasarana dalam pembelajaran daring mutlak untuk diperhatikan dan terus ditingkatkan. Institusi juga haruslah menyediakan platform media pembelajaran online yang dapat diakses secara bebas tanpa terhambat waktu mengajar yang terbatas. Oleh karena itu, institusi perlu menyediakan fasilitas tersebut kepada dosen sehingga perkuliahan dapat berjalan baik dan optimal. Institusi juga perlu mengembangkan Learning Manajemen System (LMS) kampus yang user friendly.

\section{KESIMPULAN}

Pembelajaran daring di
perguruan tinggi memberikan pengalaman baru bagi pendidik maupun mahasiswa. Pada awal diimplementasikannya pembelajaran daring mahasiswa cukup mengalami kesulitan sehingga diperlukan adaptasi. Berdasarkan persepsi mahasiswa, diketahui bahwa mereka memiliki kecenderungan untuk lebih memilih pembelajaran luring daripada daring. Hal tersebut dikarenakan pada pembelajaran luring, lebih banyak komunikasi yang terbentuk di kelas. Kecakapan dalam penggunaan teknologi juga menjadi faktor penentu dalam keberhasilan pembelajaran daring. Baik dosen maupun mahasiswa keduanya memberikan sumbangsih dalam kesuksesan penyelenggaraan pembelajaran daring, selain itu juga perlu dukungan sarana dan prasarana yang memadai dari institusi.

\section{SARAN}

Institus pendidikan perlu memetakan persepsi dan faktor penentu dalam keberhasilan pembelajaran daring. Hal tersebut nantinya dapat digunakan institusi pendidikan dalam hal ini perguruan tinggi untuk mengambil kebijakan sehingga bisa dapat digunakan untuk landasan dalam pengambilan keputusan. Penelitian lain tentang metode dan strategi pembelajaran daring juga perlu dilakukan untuk mengetahui efektifitas penggunaannya dalam pembelajaran daring. Terlepas dari adanya pandemi Covid-19 maka tidak bisa dipungkuri bahwa kedepan perkembangan kearah pembelajaran blended learning sangat dimungkinkan terjadi.

\section{DAFTAR RUJUKAN}

Adijaya, N dan Santosa, L. P. 2018. Persepsi Mahasiswa dalam Pembelajaran Online. Jurnal Wanastra. 10 (2): 105-110.

Anshori, S. 2018. Pemanfaatan Teknologi Informasi dan Komunikasi sebagai Media Pembelajaran. Jurnal Ilmu Pendidikan PKn dan Sosial Budaya, 2 (1): 88-100.

Aswasulasikin, A. 2020. Persepsi Mahasiswa terhadap Kuliah daring di masa Pandemi Corona Virus Disease (Covid-19). Dikutip dari https://www.researchgate.net/pub lication/341624707.

Chaeruman, U. A. 2017. Alur Belajar: Meningkatkan Interaktivitas Pembelajaran Daring. Seminar dan Lokakarya Pembelajaran Daring di Perguruan Tinggi Kementerian Riset, Teknologi, dan Pendidikan. 
Dewi, W. A. F. 2020. Dampak Covid19 terhadap Implementasi Pembelajaran Daring di Sekolah Dasar. Edukatif: Jurnal Ilmu Pendidikan. 2 (1): 55-61.

Firman, F dan Rahayu, S. 2020. Pembelajaran Online di Tengah Pandemi Covid-19. Indonesian Journal of Educational Science (IJES), 2 (2):81-89.

Fitriyani, Y., Fauzi., dan Sari, M. Z. 2020. Motivasi Belajar Mahasiswa pada Pembelajaran daring selama Pandemik Covid19. Jurnal Kependidikan: Hasil Penelitian dan Kajian Kepustakaan di Bidang Pendidikan, Pengajaran, dan Pembelajaran. 6 (2): 165-175.

Hadi, L. 2020. Persepsi Mahasiswa terhadap Pembelajaran Daring di Masa Pandemik Covid-19. Jurnal Zarah, 8 (2): 56-61.

Harjanto, T., \& Sumunar, D. S. E. W. (2018). Tantangan Dan Peluang Pembelajaran Dalam Jaringan: Studi Kasus Implementas Elok (E-Learning: Open For Knowledge Sharing) Pada Mahasiswa Profesi Ners. Jurnal Keperawatan Respati Yogyakarta, 5: 24-28.

Jamaludin, D., Ratnasih, T., Gunawan, H., dan Paujiah, E. 2020. Pembelajaran Daring Masa Pandemik Covid-19 pada Calon Guru: hambatan, Solusi, dan Proyeksi. Karya Tulis Ilmiah, Lembaga Penelitian dan Pengabdian kepada Masyarakat UIN Sunan Gunung Djati: Bandung.

Kartini, S., H. Widiowati., \& T. Asih. 2020. Pembelajaran Daring Berbasis Metode Team Assisted Individualization (TAI) untuk Optimalisasi Nilai Kognitif Peserta Didik. Jurnal Pendidikan Biologi Bioedukasi 11 (2): 126130.
Masykhur, M.A., dan Risnani, L.Y. 2020. Pengembangan dan Uji Kelayakan Game Edukasi Digital sebagai Media Pembelajaran Biologi Siswa Kelas X pada Materi Animalia. Bioedukasi: Jurmal Pendidikan Biologi, 11 (2): 90-104.

Miles, M., B., dan Huberman, M. 1994. Qualitative Data Analysis: Second Edition. SAGE Publications.

Milman, N. B. 2015. Distance Education. International Encyclopedia of the Social and Behavioral Sciences: Second Edition. https://doi.org/10.1016/B978-008-097086-8.92001-4

Pangondian, R.A., Santosa, P.I, dan Nugroho, E. 2019. Faktor-faktor yang Mempengaruhi Kesuksesan Pembelajaran daring dalam revolusi Industri 4.0. Prosiding Seminar nasional Teknologi Komputer dan sains (SAINTEKS), 1 (1): 56-60.

Pilkington, O. A. 2018. Active Learning for an Online Composition Classroom: Blogging as an Enhancement of Online Curriculum. Journal of Educational Technology Systems, 47 (2): 1-14.

Pratiwi, E.W. 2020. Dampak Covid-19 terhadap Kegiatan Pembelajaran Online di Sebuah Perguruan Tinggi Kristen di Indonesia. Perspektif Ilmu Pendidikan, 34 (1): 1-8.

Rahadian, D. Teknologi Informasi dan Komunikasi (TIK) dan Kompetensi Teknologi Pembelajaran untuk Pengajaran yang Berkualitas. Jurnal Teknologi Pendidikan dan Pembelajaran (JTEP), 2 (1): 234254. 
Riaz, A. 2018. Effects of Online Education on Encoding and Decoding Process of Students and Teachers. International Conference E-Learning, 42-48. https://files.eric.ed. gov/fulltext/ ED5 90288.pdf.

Ristekbrin. 2017. Buku Panduan Pengisian Survei Pembelajaran dalam Jaringan. (Online). Diakses dari: https://www.ristekbrin.go.id/wpcontent/uploads/2017/04/BukuPanduan-Survei-PembelajaranDaring-27032017-new.pdf.

Rusdiana, E., dan Nugroho, A. (2020). Respon Mahasiswa Pada Pembelajaran Daring Bagi Mahasiswa Mata Kuliah Pengantar Hukum Indonesia UNESA. Jurnal Integralistik, 31 (1), 1-12.

Sadikin, A dan Hamidah, A. 2020. Pembelajaran Daring di tengah
Wabah Covid-19. Biodik: Jurnal Ilmiah Pendidikan Biologi, 6 (2): 214-224.

Saragih, O., Sebayang, F. A. A., Sinaga, A. B., dan Ridlo, M.S. 2020. Persepsi Mahasiswa terhadap Pembelajaran Daring selama Pandemi Covid-19. Tarbiyah Wa Ta'lim: Jurnal Penelitian Pendidikan dan Pembelajaran. 7 (3): 178-191.

Sulistio, A. 2021. Peningkatan Prestasi Belajar Bahasa Inggris melalui Pembelajaran Jarak Jauh (PJJ) dalam Penerapan Pembelajaran Sinkron dan Asinkron melalui Google Classroom, Google Meet, dan Aplikasi E-Learning. Jurnal Secondary: Jurnal Inovasi Pendidikan kejuruan, 1 (2): 6369.

Suryani, Y.E. 2010. Kesulitan Belajar. Jurnal Magistra, 22 (73): 33-47. 